\title{
Postnatal growth and development of Natalus mexicanus (Chiroptera: Natalidae)
}

\author{
Matías Martinez-Coronel' ${ }^{1}$ Anubis Molina Gutiérrez ${ }^{1}$, and Yolanda Hortelano-Moncada ${ }^{2 *}$ \\ ${ }^{1}$ Departamento de Biología, UAM-Iztapalapa. Av. San Rafael Atlixco 186, Col. Purísima, Iztapalapa. CP. 09340. Ciudad de México, \\ México. Email: marti17@hotmail.com (MM-C), abis07.77@gmail.com (AMG). \\ ${ }^{2}$ Departamento de Zoología, Instituto de Biología, Universidad Nacional Autónoma de México, Circuito Deportivo s/n, Ciudad \\ Universitaria CP. 04510. Ciudad de México, México. Email: yolahm@ib.unam.mx (YH-M). \\ *Corresponding author
}

Natalus mexicanus is a bat species distributed from northern México to Central America. It inhabits various types of tropical vegetation, roosting mainly in caves with high relative humidity and temperature, and feeding mostly on arachnids. This study investigated postnatal growth and flight development of populations under natural conditions inhabiting "Los Laguitos" cave, Chiapas, southern México. Forty-four females and 50 males were monitored from birth to 55 days of age; at five-day intervals, we measured body mass, forearm length, cartilaginous epiphyseal gap of the fourth metacarpal-phalangeal joint, and development of four characters. We used statistical analyses and growth models to quantify the changes in morphometric parameters. Neonates are altricial; the ears began to unfold since day one, while the eyes opened at day 25. Greyish hair appeared between 25 to 35 days. Forearm length and body mass increased linearly over 35 days, then the growth rate decreased. The cartilaginous epiphyseal gap increased in size until day 25 and then started to close. The logistic equation yielded the best fit for forearm length $(K=0.07)$ and body mass $(K=0.10)$. Sustained flight was first achieved at 35 days of age. $N$. mexicanus neonates are altricial and relatively small compared with other bats. Eye-opening and fur development took place at a slower rate than in most species of insectivorous bats. In the Chiapas population, eye-opening, fur development, and volancy occurred more slowly relative to the population inhabiting Álamos, Sonora. These differences are probably consequences of local variations. The morphometric postnatal growth pattern of $N$. mexicanus was like that of other insectivorous bats, i. e., linear growth rate before the onset of flight and slowing down thereafter. As in other studies, the logistic model best fitted the growth pattern of body mass and forearm length, but growth coefficients were lower versus other tropical bats. The cartilaginous epiphyseal gap of the fourth digit closes at an intermediate age relative to other insectivorous bats. Sustained flight was attained when the relative body mass and forearm length of individuals approached adult body dimensions, as in other bat species.

Natalus mexicanus se distribuye desde México hasta Centroamérica. Este murciélago se refugia principalmente en cuevas con elevada humedad relativa y temperatura. Habita diferentes tipos de vegetación tropical y se alimenta sustancialmente de arácnidos. Debido a que es una especie con amplia distribución y que no existe información sobre el crecimiento postnatal y desarrollo para las poblaciones del sur de México, en el presente trabajo se realiza un estudio bajo condiciones naturales en la cueva "Los Laguitos" Chiapas, México. Se midió el desarrollo de algunos caracteres y los cambios de la masa corporal, longitud del antebrazo, epífisis cartilaginosa metacarpo-falange del cuarto dedo cada cinco días, desde el día del nacimiento hasta los 55 días de edad, en 44 hembras y 50 machos. Para analizar los datos se emplearon una prueba de T de Student y tres modelos de crecimiento. Los neonatos son altricios, las orejas empezaron a separarse desde el primer día, mientras que los ojos se abrieron hasta los 25 días. El pelaje grisáceo apareció entre los 25 a 35 días. La longitud del antebrazo y masa corporal crecieron linealmente hasta los 35 días, después el incremento disminuyó. La ecuación logística ofreció el mejor ajuste para los datos de longitud del antebrazo $(K=0.07)$ y masa corporal $(K=0.10)$. La epífisis cartilaginosa aumentó hasta el día 25 y después empezó a cerrarse. El vuelo sostenido inició a los 35 días de edad. En comparación con otros microquirópteros, los neonatos de $N$. mexicanus son relativamente pequeños y altricios. La apertura de los ojos y desarrollo del pelaje fueron más lentos en comparación con la mayoría de las especies insectívoras. En la población de Chiapas, la apertura de los ojos, desarrollo del pelaje y vuelo fueron más lentos en comparación con los de Álamos, Sonora. Estas diferencias se consideran resultado de variaciones locales. El patrón de crecimiento resultó similar a otros murciélagos insectívoros, fue lineal previo al inicio del vuelo, posteriormente la tasa de incremento disminuyó. Como en otros estudios, el modelo logístico fue el que mejor describió el patrón de crecimiento de la masa corporal y longitud del antebrazo, pero los coeficientes de crecimiento fueron menores con respecto a otros murciélagos tropicales. La epífisis cartilaginosa metacarpo-falange del cuarto dedo, se cierra a edad intermedia en comparación con otras especies insectívoras. El vuelo sostenido inició cuando los juveniles son casi del tamaño del adulto, como en la mayoría de las especies estudiadas.

Keywords: flight development; life strategies; "Los Laguitos" cave; neonatal size; neonates; tropical bats.

C 2021 Asociación Mexicana de Mastozoología, www.mastozoologiamexicana.org

\section{Introduction}

Postnatal development and growth are life-history traits related to reproductive success, age at onset of adulthood, and longevity (Barclay and Harder 2003). Organisms with a faster development that reach a larger size in a shorter time have advantages over organisms with a slower growth rate (Kunz and Hood 2000; Dmitriew 2011). In bats, development and growth rate are affected by inheritance, maternal health, shelter conditions, and available food resources, among others (Kunz and Hood 2000). Bats undergo accelerated growth and development, lasting about one month in most Yangochiroptera (Kunz and Hood 2000). Likewise, weaning occurs at one month of age, although it is delayed to up to nine months in vampires (Kunz and Hood 2000; Delpietro and Russo 2002). Most studies on postnatal growth in bats focus on species with temperate distribution, rather than on 
tropical species (Kunz and Hood 2000; Richardson and Kunz 2000; Lin et al. 2010; Chaverri and Vonhoff 2011). For this reason, it is valuable to estimate the parameters related to postnatal development and growth in tropical and subtropical bat species, to understand the evolution of reproductive strategies of these organisms in different environments.

Natalus mexicanus is a bat species ranges from México to Panama and in Pacific and Caribbean islands; its habitat comprises from xeric shrubland to tropical rainforest, from sea level to 2,300 masl (Tejedor 2011, 2019). This species occupies mainly caves as daytime shelters and has also been found in mines and tree holes with high temperature and relative humidity (RH), from 22 to $26{ }^{\circ} \mathrm{C}$ and 74 to $99 \%$, respectively (Torres-Flores and López-Wilchis 2010; Tejedor 2011). Its diet includes a variety of arthropods, mainly arachnids (Torres-Flores and López-Wilchis 2019). Reproductive data from a population of Sonora indicate that the species is monoestrous, mating in summer and giving birth to a single offspring (Mitchell 1965). Since the species is widespread in México and thrives in different environments, some characteristics of its life history are considered to vary, as there is no reproductive information available for populations inhabiting southern México. The present study investigated the growth and flight development in $N$. mexicanus based on a population inhabiting "Los Laguitos"cave, Tuxtla Gutiérrez, Chiapas.

\section{Materials and Methods}

Study Area. The "Los Laguitos" cave is located $4 \mathrm{~km}$ to the NW of Tuxtla Gutiérrez (16०46' N, $-93^{\circ} 8^{\prime} \mathrm{W}$; altitude 781 masl), Chiapas, México. The cave has a horizontal structure consisting of three galleries with a single entrance. Inside the cave, the mean annual temperature is $32.3^{\circ} \mathrm{C}$ and $\mathrm{RH}$ is $95.4 \%$; these values are higher than outdoor conditions (Martínez-Coronel et al. 2010). The local climate is warm subhumid, with a mean annual temperature of $24.7^{\circ} \mathrm{C}$ (Cardoso 1979); the rainy season spans from May to October, with a well-marked summer drought or canicula in July and August and a dry season the rest of the year. The local vegetation is a tropical deciduous forest (Miranda 1998).

Growth and Development. To describe and quantify the growth and development of Natalus mexicanus, numbered plastic rings were attached to specimens at birth. The rings measured $4 \mathrm{~mm}$ in diameter by $4 \mathrm{~mm}$ width, with a mean weight of $0.04 \mathrm{~g}$. The ring was attached around the right forearm in females and on the left forearm in males. Newborn specimens were determined based on the presence of fresh placenta (Kunz 1973), in addition to having a naked body, pink skin, folded ears, auditory meatus, closed eyes, and for being unable to move away from the perch site (Martínez-Coronel et al. 2014).

Individuals were recaptured at five-day intervals until their flight capacity made it impossible to locate and catch them. The age categories included were as follows: 1, 5, 10, $15,20,25,30,35,40,45,50$ and 55 days post-birth, corresponding to the chronological age. After day 55, the cap- ture of individuals was no longer possible due to the high number of individuals in the cave. Each specimen was individually manipulated next to its perch; on each occasion, the site, recapture date, ring number, and sex were recorded.

The separation of the ears, opening of the eyes, and emergence of the fur are continuous phenomena; however, for descriptive purposes, these characteristics were classified into discrete categories, defined as follows. As regards ears, three categories were recognized: Folded ears - ears attached to the sides of the head, with the auditory meatus closed. Partially upright ears - auditory meatus open, ears separated from the head, but with the tip bent. Upright ears - ears completely upright, as in adults. For the opening of the eyes, we defined three categories: Closed eyes - eyes completely covered by the eyelids, which are fused; separation line not visible. Partially opened eyes - eyes do not open completely, because the eyelids remain fused at the lateral commissures. Opened eyes - eyes completely visible, as the eyelids are fully separated. Regarding pigmentation and fur, five categories were used: I) pink skin, body completely naked; vibrissae absent, with only red spots observed in sites where vibrissae will emerge. II) Light-pink body, off-white membranes; vibrissae present; hairs smaller than $2 \mathrm{~mm}$ in genitals and toes. III) Grayish dorsum, with darker crown, interscapular region, patagium, forearm, and legs; shiny patagium and pinkish abdomen. IV) Pigmented abdomen; body covered with short grayish hairs measuring less than $3 \mathrm{~mm}$ between legs and hips. V) Fur darker, with brown hair on the dorsum and whitish hair in the abdomen; fur longer on legs and dorsum ( $>3 \mathrm{~mm}$ ) than on the abdomen.

Also, the forearm length and the length of the epiphyseal gap of the fourth metacarpal-phalangeal joint of the right wing were measured to the nearest $0.05 \mathrm{~mm}$ with a Mitutoyo digital caliper (Kunz and Anthony 1982); body mass was measured to the nearest $0.1 \mathrm{~g}$ with a spring balance. Temperature and $\mathrm{RH}$ were also recorded in each visit using a Taylor psychrometer. The readings were taken at 21:00 and $2: 30 \mathrm{~h}$ at the center of the roost and at $1.20 \mathrm{~m}$ height.

Growth was quantified through the changes in forearm length, length of the cartilaginous epiphyseal gap of the fourth metacarpal-phalangeal joint of the right-wing, and body mass (Kunz and Anthony 1982). Flight development was described using the three categories proposed by Stern et al. (1997), namely: non-volant, individuals who hang from walls and are unable to fly, remaining still in the perching site or moving only through walls; semi-volant, individuals who attempt to fly but fail in staying in the air, colliding with walls and failing to perch; volant, individuals capable of flying in a straight line, gaining height and succeeding to perch.

Statistical analysis. The basic statistics, i. e., mean, and standard deviation, were calculated for all variables. Differences between sexes in individuals of the same age were evaluated with a Student's- $t$ test. This method was used for being robust to deviations from normality, as the sample sizes analyzed were small for the older age classes. 
To determine the growth rate of each variable, the linear portion of each empirical curve was considered separately, and a linear regression was applied to estimate the slope. To obtain the growth model with the best fit for the relationship between age and forearm length, as well as between age and body mass, we used the growth equations of Gompertz, Von Bertalanffy and the logistic model (Zullinger et al. 1984). In the case of the length of the epiphyseal cartilage of the fourth metacarpal-phalangeal joint, different polynomial models were used (Brown and Rothery 1994). All statistical analyses were performed in NCSS (2020). A value of $\leq$ 0.05 was used as a statistical significance criterion.

\section{Results}

We studied a total of 94 neonates ( 44 females and 50 males) of N. mexicanus specimens inhabiting "Los Laguitos" cave. All the individuals studied belonged to single-pup litters, as confirmed through the examination of pregnant females collected in previous months and at the beginning of the study. The parturition period lasted 25 days, from 25 May to 19 June 2009. During the day, pups slept hanging from their mothers, while at night, when mothers went out to forage, pups were transported to communal sites or nurseries, with mothers returning several times to breastfeed their pups along night. The mean temperature in the nursery was $32.8 \pm 0.55^{\circ} \mathrm{C}$; this fluctuated over the first 30 days and tended to stabilize thereafter. $\mathrm{RH}$ was $96.8 \pm 2.71 \%$, increasing from the beginning of the study to 45 days, tending to decrease thereafter.

Neonate condition. All neonates had umbilical cord and placenta; the abdominal skin was translucent, with visible viscera; ears folded and attached to the head; auditory meatus and eyes closed; pink body and skin completely devoid of hair. Red spots were observed in sites where vibrissae were to emerge. The patagium and uropatagium were whitish; the skull lacked the anterior fontanel but showed the posterior fontanel between the occipital and parietals; fat in shoulders and supra-scapular area (Figure 1a). Neonates emitted audible sounds and remained still at the site where they were left by their mothers, moving their heads upon hearing any sound; they attempted to suck milk when an object was brought closer.

Development of ears, fur, and eye opening. The ears began to separate from day one, and by day five of age, all recaptured specimens already had the auditory meatus open and the ears separated with the tip slightly bent. At day 10 of age, most individuals already had their ears fully upright (Table 1). The eyes remained closed over the first 15 days post-birth; in some 20-day individuals, the eyelids began to separate, disclosing the eyes in mid portion, as the lateral commissures remained attached. The last specimens with semi-closed eyes were 35 days old, although in other 25-day-old specimens the eyelids were already separated, and the eyes were fully open (Table 1 ).

The growth of the fur was slowly; individuals remained pink and naked during the first five days post-birth
Table 1. Detachment of the ears and opening of the eyes in Natalus mexicanus inhabiting "Los Laguitos" cave, Chiapas, Mexico. For each age category, the number of individuals in each development stage of each character is given.

\begin{tabular}{|c|c|c|c|c|c|c|}
\hline \multirow{2}{*}{$\begin{array}{l}\text { Age/ } \\
\text { days }\end{array}$} & \multicolumn{3}{|c|}{ Ear detachment } & \multicolumn{3}{|c|}{ Eye opening } \\
\hline & Folded & Semi-erect & Erect & Closed & Semi-open & Open \\
\hline 1 & 93 & 1 & & 94 & & \\
\hline 5 & & 33 & & 33 & & \\
\hline 10 & & 3 & 20 & 23 & & \\
\hline 15 & & & 24 & 24 & & \\
\hline 20 & & & 11 & 8 & 3 & \\
\hline 25 & & & 14 & 11 & 2 & 1 \\
\hline 30 & & & 11 & 6 & 4 & 1 \\
\hline 35 & & & 12 & 1 & 4 & 7 \\
\hline 40 & & & 12 & & & 12 \\
\hline 45 & & & 3 & & & 3 \\
\hline 50 & & & 4 & & & 4 \\
\hline 55 & & & 3 & & & 3 \\
\hline
\end{tabular}

(Figure 1a). Between 10 and 15 days of age, vibrissae had already grown, and hairs less than two $\mathrm{mm}$ long were observed in the genital area and toes (Table 2). At postnatal day 15 , some individuals had the crown and dorsum darker than the rest of the body (Figure 1b), a condition that occurred up to day 35 in some individuals. However, in other 30-day-old individuals, the body was already covered with a grayish fur $(<2 \mathrm{~mm})$, with the abdomen paler than the dorsum (Figure 1c). Also, in some 35-day-old individuals, the dorsum was covered with a dark brown fur more than three $\mathrm{mm}$ in length, being shorter and lighter-colored in the abdomen (Figure 1d).

Neonates had a forearm length of $10.68 \pm 0.54 \mathrm{~mm}$ in females and $10.72 \pm 0.73 \mathrm{~mm}$ in males, representing

Table 2. Development of the fur in Natalus mexicanus inhabiting "Los Laguitos" cave, Chiapas, Mexico. For each age category, the number of individuals in each development stage is given. I) pink skin, body completely naked, with no vibrissae. II) light-pink body, white membranes; vibrissae have emerged, hair on genitals and toes. III) grayish dorsum, with darker crown, interscapular region, patagium, forearm, and legs; bright patagium and pink abdomen. IV) pigmented abdomen; body covered with gray and short hair. V) all skin darker, with brown hair on the dorsum and whitish hair in the abdomen.

\begin{tabular}{|c|c|c|c|c|c|c|}
\hline \multirow{2}{*}{ Age/days } & \multicolumn{6}{|c|}{ Category } \\
\hline & $\mathbf{I}$ & II & III & & IV & v \\
\hline 1 & 94 & & & & & \\
\hline 5 & 33 & & & & & \\
\hline 10 & 5 & 18 & & & & \\
\hline 15 & & 21 & & 3 & & \\
\hline 20 & & 8 & & 3 & & \\
\hline 25 & & 8 & & 6 & & \\
\hline 30 & & 3 & & 7 & 1 & \\
\hline 35 & & & & 2 & 6 & 4 \\
\hline 40 & & & & & 3 & 9 \\
\hline 45 & & & & & 1 & 2 \\
\hline 50 & & & & & 1 & 3 \\
\hline 55 & & & & & & 3 \\
\hline
\end{tabular}




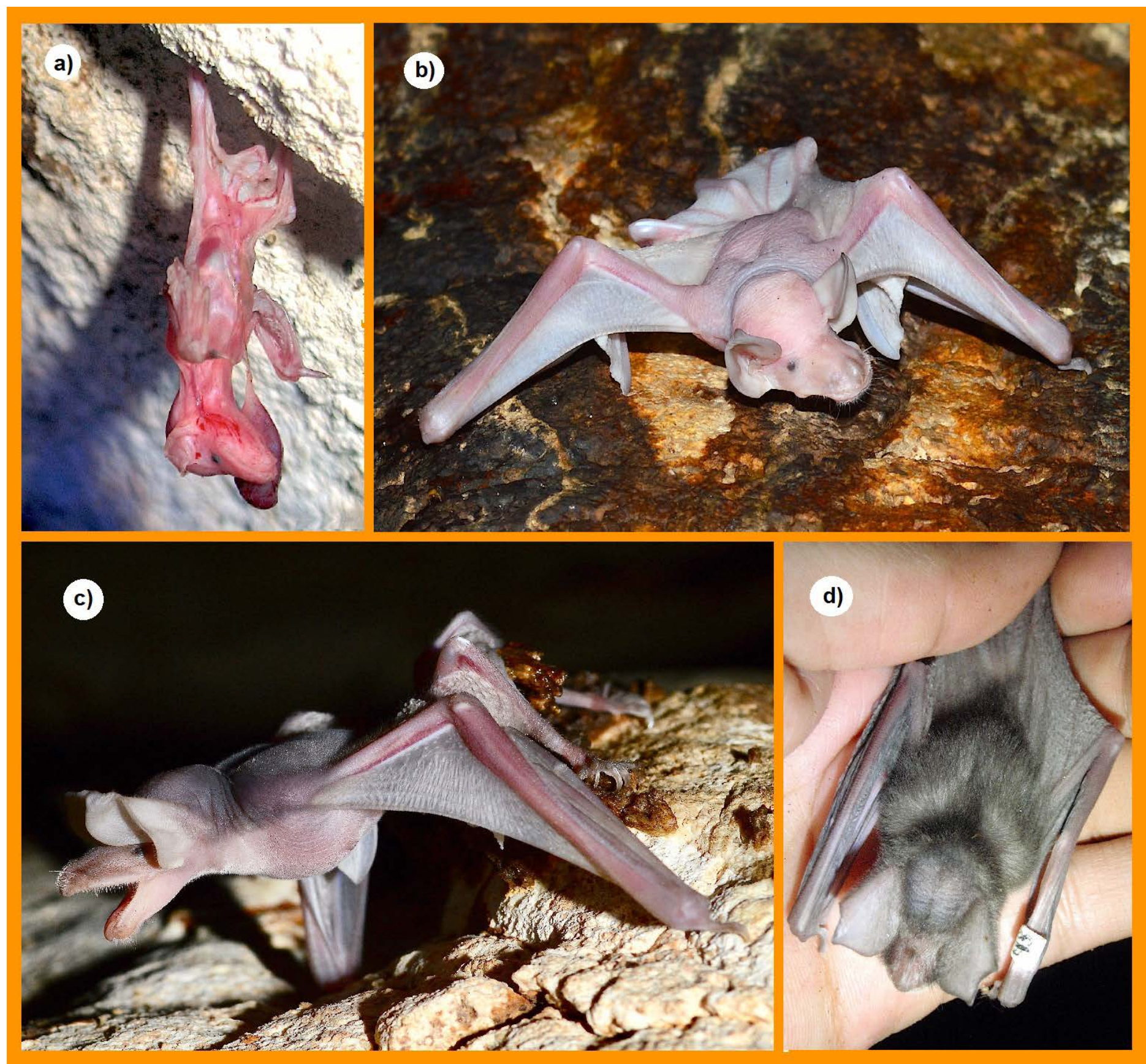

Figure 1. Specimens of Natalus mexicanus of different ages observed in "Los Laguitos" cave, Chiapas, Mexico, in 2009. a) Neonate with placenta, closed eyes, folded ears, pink, and naked body. b) 15-day-old individual with closed eyes; pigmentation appears in the dorsum and crown. c) 30-day individual with open eyes and covered with fine grayish fur; and d) 40-day individual covered with dark fur.

$27.15 \%$ and $27.26 \%$, respectively, of postpartum females. Body mass was $0.93 \pm 0.21 \mathrm{~g}$ in females and $1.03 \pm 0.22 \mathrm{~g}$ in males, representing $17.27 \%$ and $19.20 \%$ of postpartum females. The epiphyseal gap measured $2.3 \pm 0.25 \mathrm{~mm}$ in females and $2.4 \pm 0.27 \mathrm{~mm}$ in males.

Secondary sexual dimorphism. Of the three morphometric variables analyzed, only neonate body mass showed significant differences between sexes $\left(T_{93}=2.37, p=0.01\right)$, while sexes were statistically similar across the rest of the age categories. As regards forearm length and epiphyseal cartilage length, no differences between sexes were significant in any age category $(P>0.05)$; thus, data for both sexes were pooled together for subsequent analyses to increase the sample size.
Growth. Forearm length and body mass increased continuously over 55 days post-birth (Table 3 ). In the first 35 days, these variables increased linearly at a rate of 0.72 $\mathrm{mm} /$ day in length of and $0.07 \mathrm{~g} /$ day in body mass. After day 35 , the growth rate of both variables decreased to $0.19 \mathrm{~mm} /$ day and $0.05 \mathrm{~g} /$ day, respectively (Figure $2 \mathrm{a}, \mathrm{b}$ ). The length of the epiphyseal gap increased over the first 25 days post-birth at $0.098 \mathrm{~mm} /$ day, and then closed at $0.075 \mathrm{~mm} /$ day (Table 3, Figure 2b).

Growth models. Of the three models used to describe the forearm and body mass growth patterns, the logistic model yielded the best fit; therefore, the only equations shown below correspond to this model: forearm $=42.44$ / $\left(1+3.29^{-0.07 \text { (age) })}, R^{2}=0.96 ;\right.$ mass $=5.67 /\left(1+4.63^{0.10(\text { age })}\right)$, 
$R^{2}=0.91$. For its part, the growth pattern of the length of the epiphyseal gap fitted a second-order polynomial model (epiphyseal gap length $=-0.0032 x^{2}+0.1678 x+2.2084, R^{2}=$ 0.80 ; Figure $2 \mathrm{a}, \mathrm{b})$, which predicts the complete closure or calcification of the cartilaginous epiphysis between 63 and 64 days of age.

Flight development. At birth, $100 \%$ of neonates were classified as non-volant. The first individual classified as a semi-volant was 20 days old, and the first to achieve sustained flight was 35 days old. At 50 and 55 days of age, all recaptured specimens were volant (Table 4). The number of specimens recaptured after day 1 post-birth decreased with time, because after marking, some pups were moved from the original perch site by the mother. Besides, as pups developed, they began moving through the walls and mingling with the rest of the population; finally, when they started flying, they flew away from the nursery as soon as they noticed our presence, so recapturing them became impossible.

\section{Discussion}

Natalus mexicanus uses daytime shelters with temperatures ranging from 25.0 to $36.6{ }^{\circ} \mathrm{C}$ and $\mathrm{RH}$ above $74 \%$ (Mitchell 1965; Torres-Flores and López-Wilchis 2010). These conditions occur all year round in "Los Laguitos", maintaining a mean temperature of $32.3{ }^{\circ} \mathrm{C}$ and RH of $95.4 \%$ (MartínezCoronel et al. 2010) and were above average during the study period. The conditions inside the cave were favorable for the growth and development of pups because they are born naked and lose moisture easily (Mitchell 1965; Kunz and Hood 2000; Ruczynski 2006; Pretzlaff et al. 2010).

In "Los Laguitos" cave, the period of births of $N$. mexicanus lasted 25 days, from late May to late June; in Alamos, Sonora, it spans from late July to early August (Mitchell 1965), one month after it ended in the Chiapas population. These results differ from the findings by Tejedor (2019), who reported similar patterns in northern

Table 3. Postnatal growth of Natalus mexicanus inhabiting "Los Laguitos" cave, Chiapas, Mexico. For each age category, changes in body mass (grams), forearm length and length of the cartilaginous epiphyseal gap of the fourth metacarpal-phalangeal joint (millimeters) of the right wing are shown. For each measurement, the sample size $(n)$ and mean \pm standard deviation are shown.

\begin{tabular}{rrccl}
\hline Age/days & $\mathbf{n}$ & Weight & Forearm & Epiphysis \\
\hline 1 & 94 & $0.98 \pm 0.02$ & $10.71 \pm 0.64$ & $2.36 \pm 0.02$ \\
5 & 33 & $1.63 \pm 0.06$ & $12.70 \pm 0.15$ & $2.96 \pm 0.08$ \\
10 & 23 & $2.43 \pm 0.13$ & $16.22 \pm 1.67$ & $3.53 \pm 0.08$ \\
15 & 24 & $2.85 \pm 0.08$ & $20.05 \pm 2.02$ & $4.07 \pm 0.08$ \\
20 & 11 & $3.69 \pm 0.19$ & $24.60 \pm 2.73$ & $4.10 \pm 0.17$ \\
25 & 14 & $4.20 \pm 0.21$ & $28.74 \pm 3.05$ & $4.44 \pm 0.10$ \\
30 & 11 & $4.55 \pm 0.19$ & $31.22 \pm 3.58$ & $4.40 \pm 0.13$ \\
35 & 12 & $5.08 \pm 0.17$ & $34.41 \pm 1.23$ & $4.05 \pm 0.16$ \\
40 & 12 & $5.45 \pm 0.20$ & $36.90 \pm 1.28$ & $3.52 \pm 0.12$ \\
45 & 3 & $5.40 \pm 0.40$ & $38.00 \pm 0.42$ & $3.60 \pm 0.20$ \\
50 & 4 & $5.97 \pm 0.25$ & $38.30 \pm 2.67$ & $2.72 \pm 0.30$ \\
55 & 3 & $6.16 \pm 0.28$ & $39.20 \pm 0.30$ & $1.93 \pm 0.23$ \\
\hline
\end{tabular}
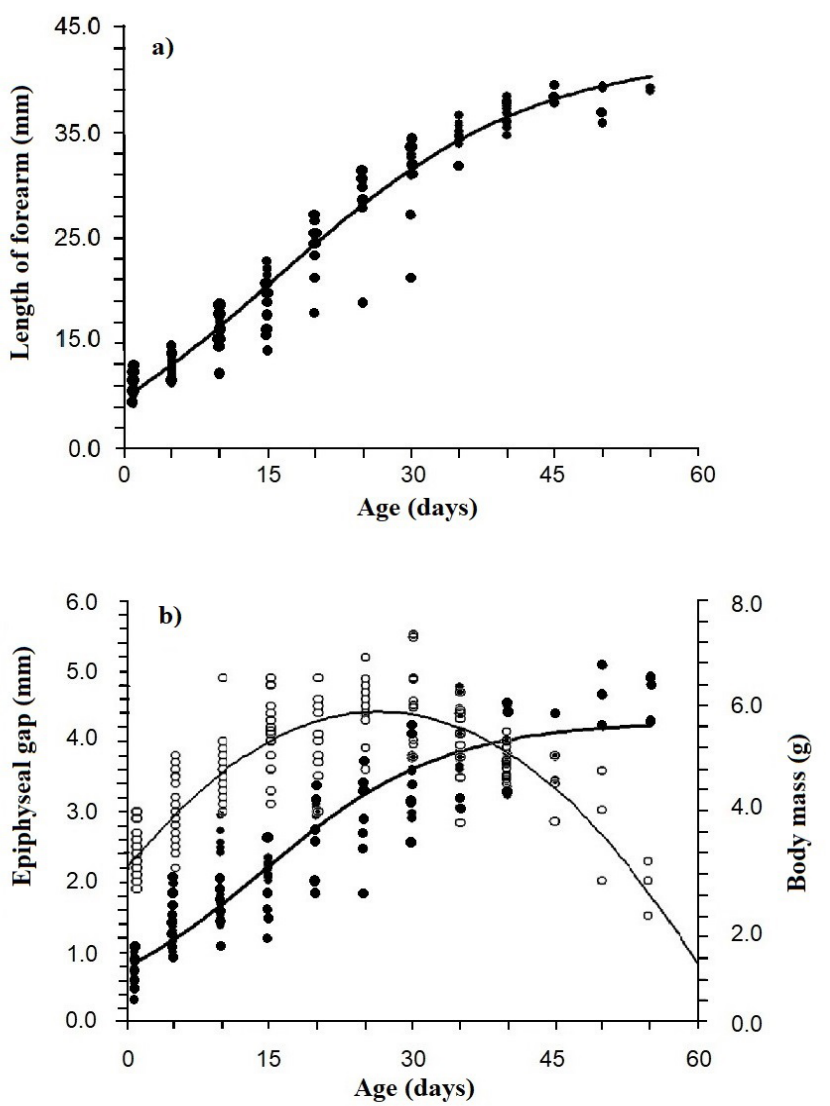

Figure 2. Growth trends of three morphometric variables evaluated in Natalus mexicanus from "Los Laguitos", Chiapas, Mexico, in 2009. a) forearm length. b) length of the cartilaginous ephiphyseal gap of the metacarpal-phalangeal joint of the fourth finger and body mass. The length of forearm and epiphysis gap curves correspond to those generated by the logistic equation model, while the one for body mass corresponds to a polynomial model.

and southern populations. However, for a species with a wide geographic distribution such as $N$. mexicanus, with populations that do not migrate latitudinally, differences are likely to exist because of local adaptations to different conditions (Kunz and Hood 2000; Barclay and Harder 2003). Geographic differences in birth season, growth, and postnatal development have also been reported for Leptonycteris yerbabuenae and Miniopterus schreibersii (Gould 1975; Richardson 1977; Martínez-Coronel et al. 2014), species with wide distributions.

Bats give birth to altricial pups, although there are differences in the degree of development between species (Kunz and Hood 2000). Examples of neonates that are born with the body covered with hair and open eyes and auditory meatus include Rosettus leschenaulti and $R$. amplexicaudatus (Elangovan et al. 2002; Giannini et al. 2006), Artibeus sp., Carollia perspicillata, Desmodus rotundus, Diphylla ecaudata, Glossophaga sp., and Uroderma bilobatum (Kleiman and Davis 1979; Kunz and Hood 2000; Delpietro and Russo 2002; Cretekos et al. 2005; Reyes-Amaya and Jerez 2013; Kohles et al. 2018), Myotis albescens and Eumops patagonicus (Rodríguez et al. 2018). Most of these species thrive in tropical areas, use outdoor shelters, and neonates are carried around by their mothers during foraging from day one post-birth (Kleiman and Davis 1979; Hernández-Mijangos et al. 2009). However, other species such as Hipposideros speoris, Leptonycteris 
yerbabuenae, Myotis emarginatus, Rhinolophus mehelyi, and Tadarida brasiliensis (McCracken and Gustin 1991; Sharifi 2004; Martínez-Coronel et al. 2014; Doss et al. 2018; Eghbali and Sharifi 2018), give birth to completely naked pups that remain with the mother during the day, presumably because of their poor thermoregulation (Studier and O'Farrel 1972). Pups are left in nurseries during the night and are recovered by mothers upon returning from foraging to be breastfed (Martínez-Coronel et al. 2014). These data contrast with studies on a population of N. mexicanus in Sonora and on Pipistrellus pipistrellus (Mitchell 1965; Hughes et al. 1995). These studies reported that pups remained separate from adults during the day and were only recovered at night to be breastfed; the authors provided no explanation for this behavior.

In the population of N. mexicanus inhabiting "Los Laguitos", Chiapas, pups are born with eyes closed and remain so for the first 15 days post-birth; eyes are completely open by day 25 . On the other hand, in a population of the same species living in Alamos, Sonora (Mitchell 1965), eyes were fully open by day 17 . The results of this study contrast with findings for some species of insectivorous bats, such as Myotis capaccinii, M. emarginatus, Pipistrellus mimus, Rhinolophus mehelyi, and Vespertilio sinensis, in which eyes open between four and eight days of age (Isaac and Marimuthu 1996; Jin et al. 2012 a, b; Eghbali and Sharifi 2018; Mehdizadeh et al. 2018), whereas in Hipposideros pomona eyes open completely until day 13 post-birth (Lin et al. 2011). Eye opening in the population of N. mexicanus studied occurs later, possibly because pups are born in a less advanced development stage compared to the other species. Likewise, the development of the fur of N. mexicanus in "Los Laguitos" follows a pattern like that of the eyes. The body remains apparently naked during the first 15 days post-birth, with long hairs evident only in the genital area and rostrum. A short, grayish fur is visible until 30 days of age, while a long, dark fur appears between 35 and 40 days old. In contrast, Mitchell (1965) reported that in the population of Sonora, the body of pups was already covered with a short fur by day 17 post-birth. In Thyroptera tricolor and $V$. sinensis, a grayish fur appears at 21 and 16 days of age, respectively (Chaverri and Vonhoff 2011; Jin et al. 2012 b), and in M. emarginatus between 25 to 30 days (Eghbali and Sharifi 2018). These data indicate that N. mexicanus is a species in which eye opening and fur development take longer.

Bats give birth to relatively large neonates compared to terrestrial mammals of the same size. This reduces the risk of dying from sudden changes in environmental temperature, relative humidity, and predation, as bat pups require less investment in parental care before reaching independence (Racey and Entwistle 2000). In N. mexicanus, the body mass of neonates is $18.23 \%$ relative to adults, a value that is below the average of $23.0 \pm 8.0 \%$ reported for Chiroptera (Barclay and Harder 2003). In other bat species, neonate body mass is equivalent to $20.7 \%$ of adult biomass in Phyllostomus hastatus (Stern and Kunz 1998), 25 \% in Tadarida brasiliensis (Kunz and Robson 1995); 26 \% in T. tricolor (Chaverri and
Table 4. Flight development in Natalus mexicanus inhabiting "Los Laguitos" cave Chiapas, Mexico. For each age category, the number of individuals in each flight development stage is given.

\begin{tabular}{|c|c|c|c|c|}
\hline \multirow{2}{*}{ Age (days) } & \multicolumn{4}{|c|}{ Category } \\
\hline & Non-volant & Semi-volant & & Volant \\
\hline 1 & 94 & & & \\
\hline 5 & 33 & & & \\
\hline 10 & 23 & & & \\
\hline 15 & 24 & & & \\
\hline 20 & 10 & & 1 & \\
\hline 25 & 9 & & 5 & \\
\hline 30 & 5 & & 6 & \\
\hline 35 & 1 & & 8 & 3 \\
\hline 40 & & & 3 & 9 \\
\hline 45 & & & 1 & 2 \\
\hline 50 & & & & 4 \\
\hline 55 & & & & 3 \\
\hline
\end{tabular}

Vonhoff 2011), 28 \% in Carollia perspicillata (Kleiman and Davis 1979) and M. lucifugus (O'Farrell and Studier 1973), $39 \%$ in H. pomona, $40 \%$ in M. capaccini (Mehdizadeh et al. 2018), and $56 \%$ in Artibeus watsoni (Chaverri and Kunz 2006).

The secondary sexual dimorphism in bats is variable; in most species, females tend to be larger than males (Ralls 1977; Hurtado et al. 2015; Ruelas 2019). In the case of smallsized species, when females are larger than males, this is a consequence of their reproductive role. During nursing, females take care of pups from conception to weaning; therefore, they must store energy during the first weeks of gestation, since by the end of pregnancy the amount of food consumed decreases because of the space occupied by the fetus (De Camargo and Oliveira 2013; Barclay and Harder 2003). Besides, carrying the fetus or pup during foraging implies a greater winged load; consequently, wings tend to be larger to improve flight performance (De Camargo and Oliveira 2013; Hurtado et al. 2015; Stevens and Platt 2015). When males are larger than females, these differences are explained as related to sexual competition (Ralls 1977). In N. mexicanus living in "Los Laguitos" cave, of the three morphometric variables analyzed, we only found significant differences in neonate body mass, with males being significantly larger than females. However, no evidence of secondary sexual dimorphism was found in the other variables at any age categories. These results are consistent with those of Tejedor (2011), who found that in adults of $N$. mexicanus the sexes are similar in forearm length and body mass.

The pattern of forearm growth, body mass, and epiphyseal gap in N. mexicanus was like that of Hipposideros cineraceus, M. capaccinii, T. brasiliensis, and T. tricolor (Kunz and Robson 1995; Jin et al. 2010; Chaverri and Vonhoff 2011; Mehdizadeh et al. 2018). In the first two variables, growth was linear in the period prior to sustained flight, which started at 35 days of age, and the growth rate decreased thereafter. Similar results were observed in the population 
of Alamos, Sonora (Mitchell 1965). During flight, wing fingers are subjected to stress; thus, phalanges must be sufficiently resistant, and the wing membrane must have a minimum area, for flapping to produce the aerodynamic force necessary to sustain the body and move it through air (Hughes et al. 1995; Stern et al. 1997; Elangovan et al. 2002). Therefore, phalanges were expected to experience accelerated growth before the onset of sustained flight, while the cartilaginous areas of the epiphyses undergo increasing calcification to avoid dislocations. In N. mexicanus, the epiphyseal gap reached its maximum size at 25 days of age, closing in the following days before sustained flight was achieved, as in other species (Stern and Kunz 1998; Lin et al. 2010; Jin et al. 2012a, b; Mehdizadeh et al. 2018). The growth model obtained predicted that the epiphysis gap should close completely at day 64 . However, this prediction could not be corroborated in the present study, since specimens could no longer be recaptured after 55 days post-birth because they mingled with the rest of the population, which included several thousands of individuals. The epiphyseal gap closure time was intermediate relative to other insectivorous species such as Pipistrelus subflavus $(6.6 \mathrm{~g})$, with closure at 45 days (Hoying and Kunz 1998); $R$. mehelyi (14 g), at 55 days (Sharifi 2004); and R. hipposideros $(8 \mathrm{~g})$, at 80 days (Reiter 2004).

As mentioned above, body mass increased in the period prior to sustained flight and no decrease was observed during the learning process, as reported for other bat species (Kunz 1973; Hughes et al. 1995; Hoying and Kunz 1998; Lin et al. 2010). Hoying and Kunz (1998) suggest that the decrease in body mass during this stage may be a consequence of the energy demand required by flight. However, Hughes et al. (1995) mention that it may be a strategy of the species, since when young bats start flying, their muscles still do not produce sufficient force and thus the wing load is greater; hence, reducing body mass facilitates learning to perform the necessary flight maneuvers. To note, these theories are not entirely satisfactory, as more than half of the species studied do not undergo a decrease in body mass during this stage; therefore, further research is needed (Hoying and Kunz 1998; Lin et al. 2010).

Of the three models used to describe the increase in body mass and forearm length in $N$. mexicanus, the logistic model best fitted the empirical data, as reported elsewhere (Hoying and Kunz 1998; Lin et al. 2010; Mehdizadeh et al. 2018). In N. mexicanus, the growth constants of body mass and forearm length were 0.10 and 0.07 , respectively. These values indicate a lower growth rate relative to other tropical insectivorous species such as $\mathrm{H}$. cineraceus, with weight and forearm values of 0.12 and 0.10 , respectively, or $\mathrm{H}$. larvatus, with 0.12 and 0.13 , respectively (Jin et al. 2010; Lin et al. 2010). Also, Kunz and Hood (2000) and Lin et al. (2010) mention that although it is valid to compare growth rates between species, it should be noted that some variables affect growth rate, such as temperature, food availability, maternal size, and colony size, which cannot be controlled by the researcher, especially in field studies.

Regardless of the degree of development of the eyes and fur in neonates, bats are altricial before flight and depend entirely on the mother during the first postnatal days (Kunz and Hood 2000). In most species, sustained flight begins when pups attain a relative mass above $70 \%$ and a forearm length of more than $90 \%$ in relation to adults (Barclay 1994; Stern and Kunz 1998). There are exceptions, as the case of $L$. yerbabuenae, which attains sustained flight when body mass is $50 \%$ and forearm length is 84 $\%$ relative to adults (Martínez-Coronel et al. 2014), while $R$. leschenautti attains it with $35 \%$ body mass and $75 \%$ forearm length (Elangovan et al. 2002). In the present study, we found that $N$. mexicanus displayed sustained flight at 35 days of age, when body mass was $86.38 \%$ and forearm length was $95.35 \%$ relative to adults. These values are above those recorded for other insectivorous species such as $M$. capaccinii, which achieves flight at day 28 , with a weight of $82.60 \%$ and forearm length of $90.31 \%$ (Mehdizadeh et al. 2018); P. mimus at day 29, with a weight of about $80 \%$ (Isaac and Marimuthu 1996); H. larvatus at day 24, with a weight of $61.4 \%$ and forearm length of $92.4 \%$ (Lin et al. 2010); R. mehelyi at day 28; with a weight of $92 \%$ and forearm length of $87 \%$ (Sharifi 2004). In contrast, in T. tricolor the onset of flight occurs up to day 60 , with a weight of $77 \%$ and forearm length of $95 \%$ (Chaverri and Vonhoff 2011); and in Artibeus watsoni flight starts at day 35, when forearm length reaches $100 \%$ and weight is $80 \%$ relative to adults (Chaverri and Kunz 2006). Except for pteropodids, these results suggest that there is no trend regarding the age at onset of flight in the different species and families studied in temperate and tropical areas, nor between insectivorous and frugivorous bats (Kunz and Hood 2000; Lin et al. 2010).

\section{Acknowledgments}

Our sincere thanks to $\mathrm{S}$. Solari and the two anonymous reviewers, whose comments improved the quality of this manuscript. Thanks also to M. Pérez and family for their support during our stay in Tuxtla Gutiérrez, Chiapas. María Elena Sánchez-Salazar translated the manuscript into English.

\section{Literature cited}

Barclay, R. M. R. 1994. Constraints on reproduction by flying vertebrates: energy and calcium. American Naturalist 144:1021-1031.

Barclay, R. M. R., AND L. D., HaRder. 2003. Life histories of bats: life in the slow lane. Pp. 209-253, in Bat ecology (Kunz, H., and M. B. Fenton, eds.). University of Chicago Press, Chicago. Brown, D., AND P. Rothery. 1994. Models in Biology: Mathematics, Statistics and Computing. Wiley. Inglaterra.

Cardoso, C. M. D. 1979. El clima de Chiapas y Tabasco. Universidad Autónoma de México. Ciudad de México, México.

ChaverRI, G., AND T. H. Kunz. 2006. Reproductive biology and postnatal development in the tent-making bat Artibeus watsoni (Chiroptera: Phyllostomidae). Journal of Zoology 270:650-656. 
Chaverri, G., And M. J. Vonhof. 2011. Reproduction and growth in a Neotropical insectivorous bat. Acta Chiropterologica 13:147-155.

Cretekos, C. J., S. D. Weatherbee, C. H. Chen, N. K. Badwaik, L. Niswander, R. R. Behringer, and J. J. Rasweiler IV. 2005. Embryonic staging system for the short-tailed fruit bat, Carollia perspicillata, a model organism for the mammalian order chiroptera, based upon time pregnancies in captive-bred animals. Developmental Dynamics 233:721-738.

De Camargo, N. F., and H. F. M. de Oliveira. 2013. Sexual dimorphism in Sturnira lilium (Chiroptera, Phyllostomidae): can pregnancy and pup carrying be responsible for differences in wing shape? PLoS ONE 8:10.1371

Delpietro, V. H. A., And R. G. Russo. 2002. Observations of the common vampire bat (Desmodus rotundus) and the hairylegged vampire bat (Diphylla ecaudata) in captivity. Mammalian Biology 67:65-78.

Dmitriew, C. M. 2011. The evolution of growth trajectories: what limits growth rate? Biological Reviews 86:97-116.

Doss, D. P. S., H. Raghuran, S. Muthuselvan, M. R. Sudhakaran, AND S. S. IsaAC. 2018. Postnatal growth and age estimation in a tropical insectivorous bat, Hipposideros speoris. International Journal of Zoology and Applied Biosciences 3:34-40.

Eghbalı, H. y M. Sharifi. 2018. Postnatal growth, age estimation, and wing development in Geoffroy's bat Myotis emarginatus (Chiroptera: Vespertilionidae). Mammal Study 43:153-165

Elangovan, V., H. Raghuram, E. Y. S. Priya, and G. Marimuthu. 2002. Postnatal growth, age estimation and development of foraging behaviour in the fulvous fruit bat Rousettus leschenaulti. Journal of Biosciences 27:695-702.

Giannini, N., A. Goswami, and M. R. Sánchez-Villagra. 2006. Development of integumentary structures in Rousettus amplexicaudatus (Mammalia: Chiroptera: Pteropodidae) during late-embryonic and fetal stages, Journal of Mammalogy 87:993-1001.

GouLD, E. 1975. Neonatal vocalizations in bats of eight genera. Journal of Mammalogy 56:15-29.

Hernández-Mijangos, L. A., A. Horváth, and R. Pérez Canales. 2009. Observations on female bats transporting non-volant juveniles during flight. Chiroptera Neotropical 15:472-476.

Hoying, K. M., AND T. H. Kunz. 1998. Variation in size at birth and pos-natal growth in the insectivorous bat Pipistrellus subflavus (Chiroptera: Vespertilionidae). Journal of Zoology 245:15-27.

Hughes, P., J. M. V. Rayner. And G. Jones. 1995. Ontogeny of 'true' flight and other aspects of growth in the bat Pipistrellus pipistrellus. Journal of Zoology (London) 235:291-318.

Hurtado, N., R. D. Sepúlveda, and V. Pacheco. 2015. Sexual size dimorphism of a sensory structure in a monomorphic bat. Acta Chiropterologica 17:75-83.

IsaAC, S. S., AND S. S. Marimuthu. 1996. Postnatal growth and age estimation in the Indian pygmy bat Pipistrellus mimus. Journal of Mammalogy 77:199-204.

Jin, L., A. Lin, K. Sun, Y. Liu, ANd J. Feng. 2010. Postnatal growth and age estimation in the Ashy leaf-nosed bat, Hipposideros cineraceus. Acta Chiropterologica 12:155-160.

Jin, L., L. Bo., K. Sun, Y. Liu, J. P. Ho, And J. Feng. 2012a. Postnatal growth and age estimation in Marsahll's horshoe bat, Rinolophus marshalli. Acta Chiropterologica 14:105-110.

Jin, L., J. Wang, Z. Zhang, K. Sun, J. S. Kanwal, and J. Feng. 2012b. Postnatal development of morphological and vocal features in Asian parti-colored bat, Vespertilio sinensis. Mammalian Biology 77:339-344.

Kleiman, D. G., And T. M. Davis. 1979. Ontogeny and maternal care. Pp. 387-402 in Biology of bats of the New World family Phyllostomidae. Part III (Baker, R. J., J. K. Jones, Jr., and D. C. Carter, eds.). Special Publications of the Museum, Texas Tech University 16:1-441.

Kohles, J.E., R. A. Page, D. K. N. Dechmann, and M. T. O'Mara. 2018. Rapid behavioral changes during early development in Peters' tent-making bat (Uroderma bilobatum). PLoS ONE 13: e0205351.

Kunz, T. H. 1973. Population studies of the cave bat (Myotis velifer): reproduction, growth and development. Occasional Papers of the Museum of Natural History, University of Kansas 15:1-43.

Kunz, T. H., And W. R. Hood. 2000. Parental care and postnatal growth in the Chiroptera. Pp. 415-468, in Reproductive biology of bats (Crichton, E. G., and P. H. Krutzsch, eds.). Academic Press.

Kunz, T. H., And E. L. P. Anthony. 1982. Age estimation and post-natal growth in the bat Myotis lucifugus. Journal of Mammalogy 63:23-32.

Kunz, T. H., And S. K. Robson. 1995. Postnatal growth and development in the mexican free-tailed bat (Tadarida brasiliensis mexicana): birth size, growth rates, and age estimation. Journal of Mammalogy 76:769-783.

LiN, A-Q., L.-R. Jin, Y. Liu, K.-P. Sun, AND J. Feng. 2010. Postnatal growth and age estimation in horsefield's leaf-nosed bat Hipposideros larvatus. Zoological Studies 49:789-796.

LiN, A.-Q., L.-R. JiN, L.-M. SHI, K.-P. Sun, S. W. Berquist, Y. Liu, AND J. Feng. 2011. Postnatal development in Andersen's leafnosed bat Hipposideros pomona: flight, wing shape, and wing bone lengths. Zoology 114:69-77.

Martínez-Coronel, M., E. García, C. Müdespacher-Zihel, and A. TORRES. 2010. El microclima de la cueva de "Los Laguitos" y su relación con los murciélagos. Mundos Subterráneos 21:74-89.

Martínez-Coronel, M., F. A. Cervantes, and Y. Hortelano-MoncaDA. 2014. Crecimiento y desarrollo postnatal del vuelo en el murciélago Leptonycteris yerbabuenae en Chiapas, México. Therya 5:303-322.

McCracken, G. F., AND M. K. Gustin. 1991. Nursing behavior in mexican free-tailed bats maternity colonies. Ethology 89:305-321.

Mehdizadeh, R. H., Eghbali, and M. Sharifi. 2018. Postnatal growth and vocalization development in the long-fingered bat, Myotis capaccinii (Chiroptera, Vespertilionidae). Zoological Studies 57: 1-13.

Miranda, F. 1998. La vegetación de Chiapas. Tercera edición. Consejo Estatal para la Cultura y las Artes de Chiapas, México. Mitchell, G. C. 1965. A natural history study of the funneleared bat Natalus stramineus. Unpublished M.Sc. thesis, University of Arizona. hdl.handle.net/10150/318407

NCSS. 2020. The Number Cruncher Statistical System. Published by NCSS. Hintze, L. J. Kaysville, Utah.

O'Farrell, M. J., And E. H. Studier. 1973. Reproduction growth and development in Myotis thysanodes and M. lucifugus (Chiroptera: Vespertilionidae). Ecology 54:18-30.

Pretzlaff, I., G. Kerth, and K. H. Dausmann. 2010. Communally breeding bats use physiological and behavioural ad- 
justments to optimise daily energy expediture. Naturwissenchaften 97:353-363.

Racey, P. A., And A. C. Entwistle. 2000. Life history and reproductive strategies of bats. Pp. 364-414 in Reproductive biology of bats (Crichton, E. G., and P. H. Krutzsch, eds.). Academic Press.

Ralls, K. 1977. Sexual dimorphism in mammals: Avian models and unanswered questions. The American Naturalist 111:917-938.

Reiter, G. 2004. The importance of woodland for Rhinolophus hipposideros (Chiroptera, Rhinolophidae) in Austria. Mammalia 68:403-410.

Reyes, Amaya, N., And A. Jerez. 2013. Postnatal cranial ontogeny of the common vampire bat Desmodus rotundus (Chiroptera: Phyllostomidae). Chiroptera Neotropical 19:1198-1211.

Richardson, C. S., AND T. H. Kunz. 2000. Growth rates and age estimation in free-ranging bats: a comparison of longitudinal and cross-sectional sampling methods. Journal of Mammalogy 81:709-781.

Richardson, E. G. 1977. The biology and evolution of the reproductive cycle of Miniopterus schreibersii and M. australis (Chiroptera: Vespertilionidae). Journal of Zoology 183:353-375.

Rodríguez, F. E., M. T. Sandoval, B. B. Álvarez, and D. M. LomBARDO. 2018. Comparative study of prenatal development between Myotis albescens (Chiroptera: Vespertilionidae) and Eumops patagonicus (Chiroptera: Molossidae): the chorionic vesicle and extraembryonic membranes considerations. The Anatomical Record 301:1527-1543.

RuczYNSKI, I. 2006. Influence of temperature on maternity roost selection by noctule bats (Nyctalus noctula) and Leisler's bats (N. leisleri) in Białowieza Primeval Forest, Poland. Canadian Journal of Zoology 84:900-907.

RuelAs, D. 2019. Variación ontogenética y dimorfismo sexual en Platalina genovensium (Chiroptera: Phyllostomidae). Revista Peruana de Biología 26: 201-210.

Sedgeley, J. A. 2001. Quality cavity microclimate as a factor influencing selection of maternity roosts by a tree-dwelling bat, Chalinolobus turberculatus, in New Zealand. Journal of Applied Ecology 38:425-438.

Sharifl, M. 2004. Postnatal Growth and Age Estimation in the Mehely's Horseshoe Bat (Rhinolophus mehelyi). Acta Chiropterologica 6:155-161.

Stern, A. A., AND T. H. Kunz. 1998. Intraspecific variation in postnatal growth in the greater spear-nosed bat. Journal of Mammalogy 79:755-763.

Stern, A. A., T. H. Kunz, and S. S. Bahtт. 1997. Seasonal wing loading and the ontogeny of flight in Phyllostomus hastatus (Chiroptera: Phyllostomidae). Journal of Mammalogy 78:1199-1209.

Stevens, R. D., and R. N. Platt. 2015. Patterns of secondary sexual size dimorphism in New World Myotis and a test of Rensch's rule. Journal of Mammalogy 96:1128-1134.

Studier, E. H., ANd M. J. O'Farrell. 1972. Biology of Myotis thysanodes and M. lucifugus (Chiroptera: Vespertilionidae) I. Thermoregulation. Comparative Biochemistry and Physiology, Part A Physiology 41:567-595.

TeJedor, A. 2011. Systematics of funnel-eared bats (Chiroptera: Natalidae). Bulletin of the American Museum of Natural History 353:1-140.
Tejedor, A. 2019. Family Natalidae (Funnel-eared bats). Pp. 584-596, in Handbook of the Mammals of the World. Volume 9. Bats (Wilson, D. E., and R. A. Mittermeier, eds.). Lynx Edicions, Barcelona.

TorRes-Flores, J.W., ANd R. López-Wilchis. 2010. Condiciones microclimáticas, hábitos de percha y especies asociadas a los refugios de Natalus stramineus en México. Acta Zoológica Mexicana (n. s.) 26:191-213.

Torres-Flores, J.W., AND R. López-Wilchis. 2019. Trophic niche and diet of Natalus mexicanus (Chiroptera: Natalidae) in a tropical dry forest of western Mexico. Acta Chiropterologica 20:343-350.

Zullinger, E. M., R. E. Ricklefs, K. H. Redford, and G. M. Mace. 1984. Fitting sigmoidal equations to mammalian growth curves. Journal of Mammalogy 65:607-636.

Associated editor: Sergio Solari

Submitted: August 20, 2020; Reviewed: September 3, 2020;

Accepted: December 12, 2020; Published on line: January 7, 2021. 
114 THERYA Vol. 12 (1): 105-113 